\title{
Influence of deposition rate and substrate temperature on structure and optical features of NiO thin film
}

\author{
O.S.Oberemok, T.M.Sabov, I.P.Lisovskyy, I.M.Khacevych, \\ O.Yo.Gudymenko, V.A.Nikirin, M.V.Voitovych
}

\author{
V.Lashkarev Institute of Semiconductor Physics, National Academy of \\ Sciences of Ukraine, 41 Nauky Ave., 03028 Kyiv, Ukraine
}

Received December 25, 2015

\begin{abstract}
Nickel oxide thin films were prepared by direct-current magnetron sputtering method at different deposition rates on unheated and heated substrates. It was shown that the deposited films are the dense arrays of nanowhiskers with the rhombohedral crystalline structure for the unheated substrate and with the face centered cubic structure for the heated substrate. Surface morphology of films consists of nanocrystalline randomly oriented grains. Increasing of the deposition rate and/or the substrate temperature lead to decrease of the film porosity and enlarge of nanocrystals. The maximum oxidation state of the deposited films is observed near the surface.

Keywords: nickel oxide films, magnetron sputtering, XRD, SNMS, FT-IR.
\end{abstract}

Тонкие пленки оксида никеля были получены методом магнетронного распыления при постоянном токе (DC) с различными скоростями осаждения на не нагретые и нагретые подложки. Осажденные пленки являются плотными массивами нановискеров с ромбоэдрической и гранецентрированной кубической кристаллическими структурами для не нагретой и нагретой подложек, соответственно. Морфология поверхности пленок состоит из нанокристаллических зерен, ориентированных случайным образом. Увеличение скорости осаждения и/или температуры подложки приводят к уменьшению пористости пленки и увеличению размеров нанокристаллов. Максимальная степень окисления осажденных пленок наблюдается вблизи поверхности.

Вплив швидкості осадження та температури підкладки на структурні та оптичні властивості тонких плівок NiO. О.С. Оберемок, Т.М. Сабов, І.П. Лісовський, І.М. Хацевич, О.Й. Гудименко, В.А. Нікірін, М.В. Войтович.

Тонкі плівки оксиду нікелю отримано методом магнетронного розпилення при постійному струмі з різними швидкостями осадження на ненагріті та нагріті підкладки. Осаджені плівки є щільними масивами нановіскерів з ромбоедричною та гранецентрованою кубічною кристалічними структурами для ненагрітої та нагрітої підкладок, відповідно. Морфологія поверхні плівок складається з випадково-орієнтованих нанокристалічних зерен. Збільшення швидкості осадження та/або температури підкладки призводять до зменшення пористості плівки і збільшення розмірів нанокристалів. Максимальний ступінь окислювання осаджених плівок спостерігається поблизу поверхні.

\section{Introduction}

Thin NiO films are $p$-type semiconductor objects with wide bandgap energy in the range of $3.5-4.0 \mathrm{eV}$, transparent to radiation in ultra- violet, visible and near-infrared regions [1]. Their use promotes the creation of advanced devices such as $p$-type transparent conducting electrodes, electrochromic display devices, UV detectors, chemical, gas and spin- 
Table 1. Parameters of NiO film deposition.

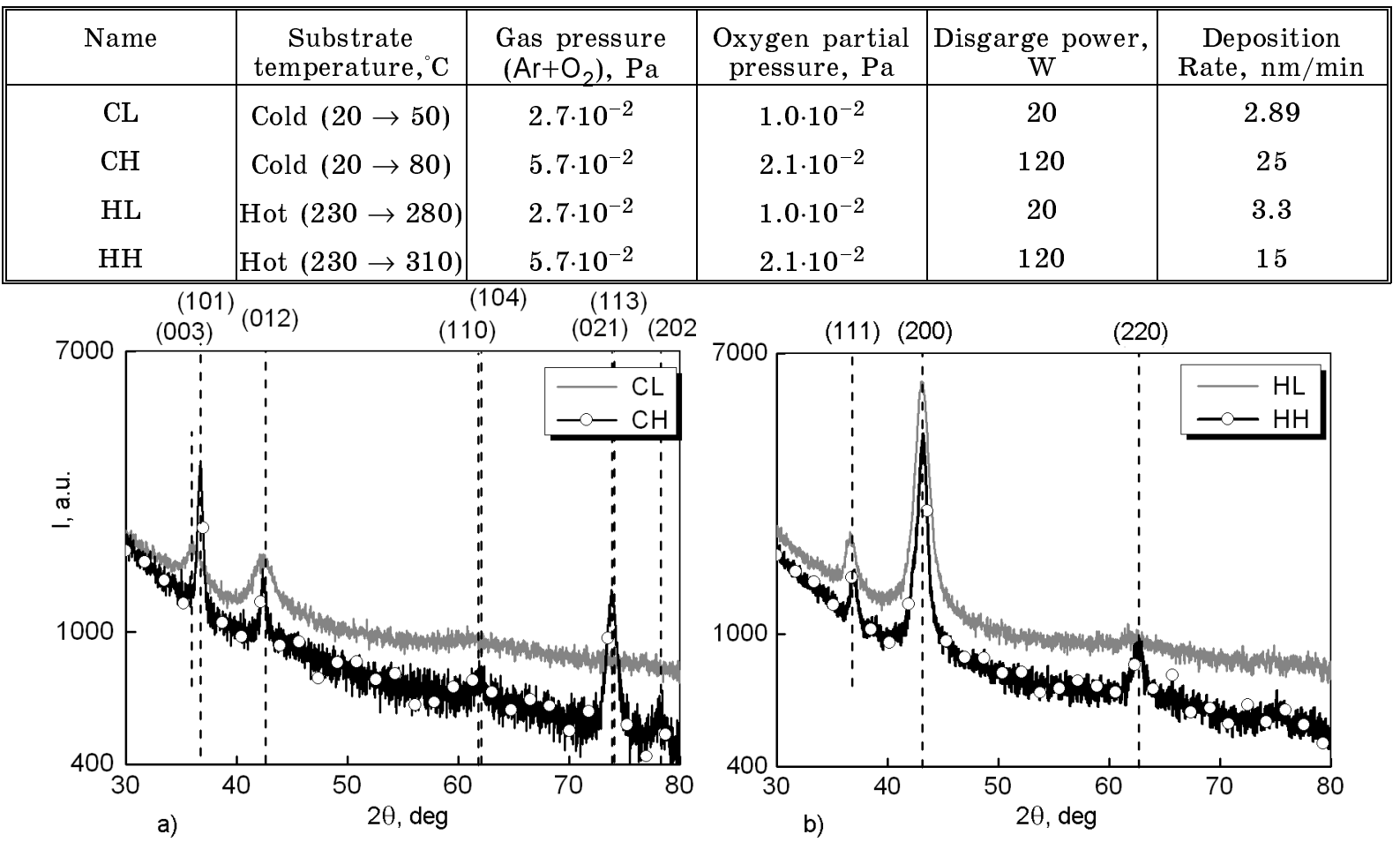

Fig. 1. XRD of NiO films deposited on quartz substrate at the room temperature (a) and at $300^{\circ} \mathrm{C}$ (b).

valve giant magnetoresistance sensors, thermoelectric devices at al. [2-5]. In most cases, the films have polycrystalline structure with the rock-salt lattice. Sizes of the crystallites (grains) essentially depend on parameters of the film synthesis. It was shown that the crystallite sizes are increased with increasing of $\mathrm{NiO}_{x}$ film thickness and substrate temperature for deposition by magnetron sputtering.

There are many different methods reported for the synthesis of $\mathrm{NiO}$ thin films, such as pulsed laser deposition, thermal or electron-beam evaporation, electrochemical deposition, spray pyrolysis etc. [6]. However, the magnetron sputtering method is used most often because the film synthesis processes are low cost and fully compatible with the technological processes of nanoelectronics.

Nickel oxide films obtained by the sputtering onto silicon and quartz substrates at different deposition rate and temperatures of heating were analyzed to understand influence of deposition conditions on the structural and optical properties of the nickel oxide films.

\section{Experimental}

Nickel oxide films were deposited on the silicon and quartz substrates by DC magnetron sputtering system from a $\mathrm{Ni}$ target of $99.95 \%$ purity in oxygen-argon mixing atmosphere. Distance between the target and the substrate was approximately $75 \mathrm{~mm}$. Before deposition the reactor chamber was pumped out to pressure of $4.2 \cdot 10^{-3} \mathrm{~Pa}$. The film depositions were carried out for 4 regimes: CL - cold substrate and low deposition rate; $\mathrm{CH}$ - cold substrate and high deposition rate, HL - heated substrate and low deposition rate; $\mathrm{HH}$ - heated substrate and high deposition rate. The basic parameters of the deposition process for each of the samples are presented in Table 1. X-Ray diffraction analyses were provided with Thermo Scientific ARL X'TRA Powder Diffractometer for the range of $30^{\circ}$ to $80^{\circ} 2 \theta$ angels. The grain sizes and surface morphology of the deposited films were studied by TSCAN MIRA 3 secondary electron microscope. Dopant distributions on the sample depth were studied with Secondary Neutral Mass Spectrometry (SNMS) method. The measurements were performed in high frequency mode of the sample sputtering by $\mathrm{Ar}^{+}$ions with energy of $300 \mathrm{eV}$ on INA-3 
et al. / ...

Table 2. Crystallite sizes and IR absorption maximums.

\begin{tabular}{||c|c|c|c|c|c||}
\hline \multirow{2}{*}{$\begin{array}{c}\text { crystallite } \\
\text { sizes, nm }\end{array}$} & Sample & CL & CH & HL & HH \\
\cline { 2 - 6 } & rhombohedral lattice, [012] & 4.3 & 12.64 & - & - \\
\cline { 2 - 6 } & $\begin{array}{c}\text { cubic lattice, [111] } \\
\text { cubic lattice, [200] }\end{array}$ & - & - & 8.41 & 7.92 \\
\hline $\begin{array}{c}\text { the position of the maximum of the infrared } \\
\text { absorption band, cm }{ }^{-1}\end{array}$ & 418 & 376 & 380 & 390 \\
\hline
\end{tabular}

(Laybold-Heraeus) instrument. Infrared spectra were measured in the spectral range of $350-7800 \mathrm{~cm}^{-1}$ with resolution of $4 \mathrm{~cm}^{-1}$ using FTIR Perkin-Elmer Spectrum BXII spectrometer working in the transmission mode at the normal incidence. To avoid influence of the silicon substrate and the native oxide layer the part of substrate was used as reference sample, i.e. the absorbance spectra of the $\mathrm{NiO}_{x}$ films under investigation were obtained by subtracting the absorbance spectrum of the reference sample from the total signal. The measurement precision of the IRtransmission spectra was $\pm 0.5 \%$.

\section{Results and discussion}

The XRD patterns of the room temperature deposited $\mathrm{NiO}_{x}$ films are presented in Fig. 1a. The films turn out to be polycrystalline and exhibit rhombohedral structure. The lattice parameters of the deposited films with a low rate (sample CL) are: $a=$ $2.9895 \AA, c=7.321 \AA$. Increase of the deposition rate results in reduction of the vertical lattice parameter $(c=7.284 \AA)$ while the parameter $a$ is not changed (sample $\mathrm{CH}$ ). The crystallite sizes (the area with perfect structure) were determined from XRD spectra by the Scherrer formula (Table 2). The data show that technological conditions of the nickel oxide film deposition influence on the crystallite sizes. The film of $\mathrm{CH}$ sample has the rhombohedral lattice.

Diffraction patterns of the films deposited at substrate temperature of $300^{\circ} \mathrm{C}$ show cubic structure of the sample $\mathrm{HL}$ and $\mathrm{HH}$ (Fig. 1b). Increase of the film deposition rate leads to decrease of the lattice parameters from $a=4.1944 \AA$ (for HL sample) to $\mathrm{a}=4.18 \AA$ (for $\mathrm{HH}$ sample).

Increasing of the substrate temperature during the nickel oxide film deposition leads to a change of the crystal structure from rhombohedral to cubic. Increasing of the deposition rate leads to a decrease of the unit cell size.

In all infra-red spectra of the as-deposited films (see Fig. 2) a rather strong ab-

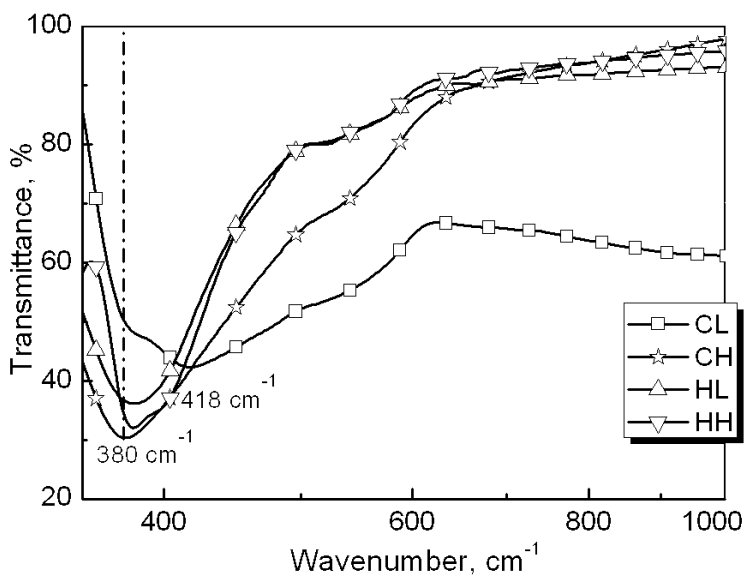

Fig. 2. IR transmission spectra of $\mathrm{NiO}$ films.

sorption band near $400 \mathrm{~cm}^{-1}$ is presented which maximum position $\left(v_{M}\right)$ and width being dependent on the conditions of $\mathrm{NiO}_{x}$ film deposition - deposition rate and temperature of the substrate. In particular, for the film deposited at slow rate $\left(\sim 2.9 \mathrm{~nm} \cdot \mathrm{min}^{-}\right.$ $\left.{ }^{1}\right)$ and at low temperature $\left(80^{\circ} \mathrm{C}\right)$ the absorption band was rather broad with two contributions with the values of $v_{M} \sim 418 \mathrm{~cm}^{-1}$ (strong) and $\sim 380 \mathrm{~cm}^{-1}$ (weak), correspondingly. Increasing of the deposition rate (up to 15-25 $\mathrm{nm} \cdot \mathrm{min}^{-1}$ ) and the deposition temperature (up $300^{\circ} \mathrm{C}$ ) leads to decay or total disappearance of the high frequency contribution.

The band observed is usually attributed to $\mathrm{Ni}-\mathrm{O}$ stretching vibrations mode for $\mathrm{NiO}$ nanoparticles with the size up to $\sim 30 \mathrm{~nm}$. Taking into account that decrease of the nanocrystals size should result in "blue" shift of their absorption mode (absorption band shifted toward larger wavenumbers) $[7,8]$ our IR data may be explained by the following way. Deposition of $\mathrm{NiO}_{x}$ on the low heated substrates and/or with small rate leads to formation of the nanocrystals with size distributed within the wide range, however the small nanocrystals are dominant. Increase of the deposition rate and the substrate temperature leads to formation of the nanocrystals with larger size distributed 

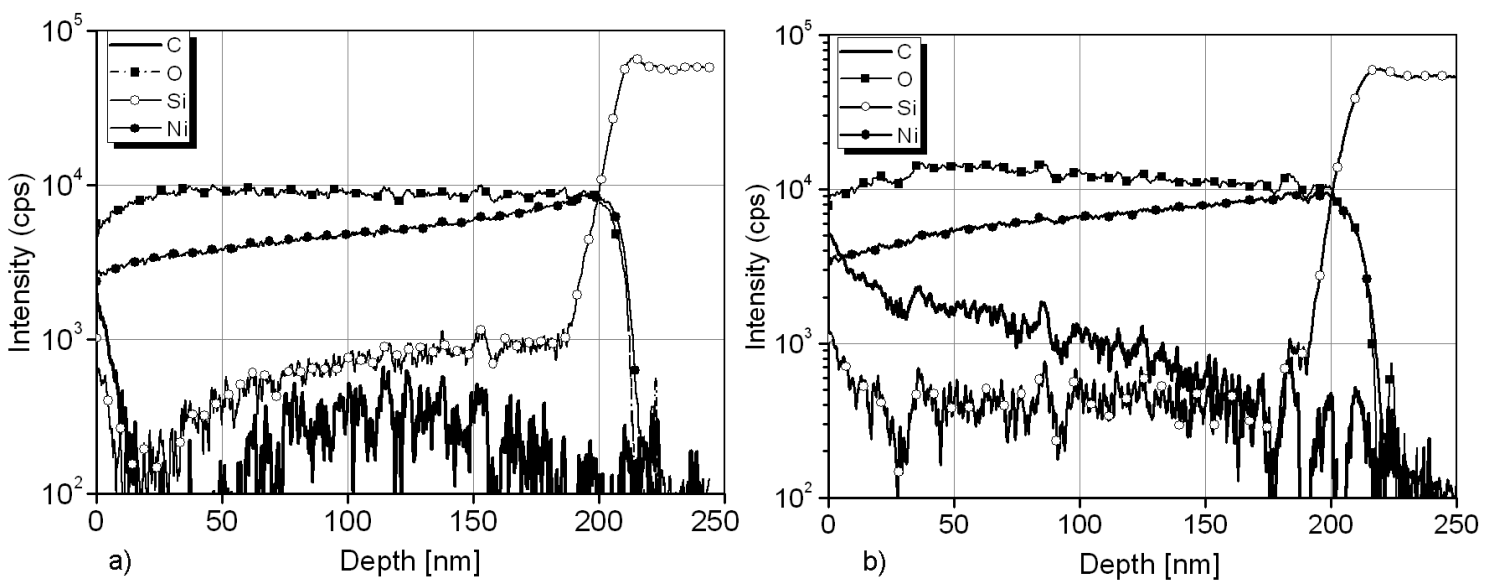

Fig. 3. SNMS depth profiles of the elements in nickel oxide films for depositions on cold (a) and heated (b) silicon substrates (CH and $\mathrm{HH}$ samples, respectively).

within the narrower range i.e. to producing more uniform assembly of the large $\mathrm{NiO}$ nanocrystals. Thus conclusions agree rather well with the data of the XRD measurements.

In the case of slow deposition (CL, HL samples) in the absorption band is clearly visible splitting into two components. It indicates formation of two arrays of crystallites with different average sizes. Such absorption band splitting is not observed during the high deposition rate. Probably the more uniform array of the crystallites is formed. The shoulder of absorption band at $550 \mathrm{~cm}^{-1}$ is decreased for the films deposited on the heated substrate (HL, HH samples), significantly. It can be specifically for the nickel oxide film with the rhombohedral crystalline structure (CL, CH samples).

In Fig. 3a,b shows the Carbon, Oxygen, Silicon and Nickel SNMS depth profiles in the $\mathrm{NiO}_{x} / \mathrm{Si}$ structures for $\mathrm{CH}$ and $\mathrm{HH}$ samples, respectively. It is seen that nickel concentration is increased from the film surface to the interface with silicon in the both cases. Moreover, the increase has an identical character. The film subsurface regions are characterized by increasing of oxygen levels and decreasing of carbon and silicon levels. The depth distributions of these elements are distinguished in the samples. $\mathrm{Ni}$ and $O$ depth profile shapes indicate the increase of the nickel oxidation degree from the $\mathrm{NiO}_{x} / \mathrm{Si}$ interface to the film surface. This may be due to porous structure of the deposited films and their additional oxidation at air atmosphere storage.

The silicon distributions indicate that the nickel oxide film deposited on the cold substrate $(\mathrm{CH})$ is more porous than the film deposited on the heated substrate (HH), i.e.

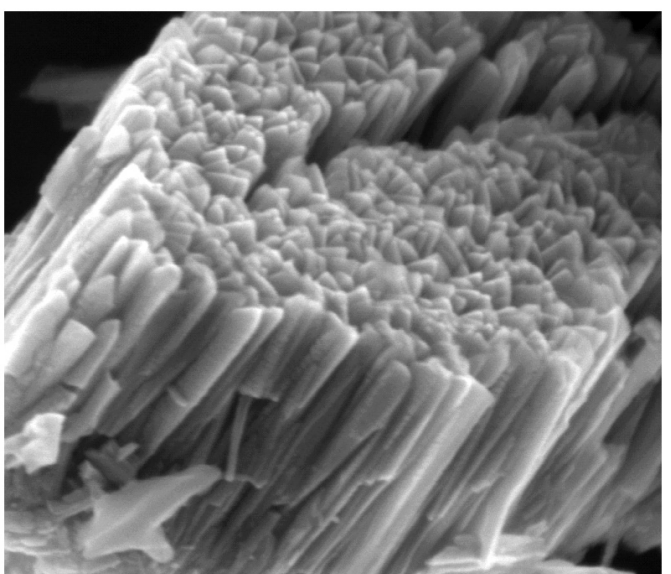

Fig. 4. SEM image of the cross cleavage of nickel oxide film (HH sample).

increasing of the substrate temperature during deposition the $\mathrm{NiO}_{x}$ film leads to formation of more dense structure. At the same time, increase of the substrate temperature results in increase of the carbon concentration in the film.

SEM image of the cross cleavage of nickel oxide film deposited on the heated substrate at the high deposition rate (sample HH) is shown in Fig. 4. The film has whiskered structure with average diameter of whiskers $\sim 30 \mathrm{~nm}$. The whiskers have a height almost the entire thickness of the film $(200 \mathrm{~nm})$. The surface topography of the film is polycrystalline with average cluster size of $\sim 30 \mathrm{~nm}$. The sizes of structurally perfect areas $(12-14 \mathrm{~nm})$ from the XRD-spectra and the cluster sizes obtained from the SEM images $(30 \mathrm{~nm})$ are distinguished. This may be because the topographical clusters consist of several crystallites with the different orientations of crystallographic planes. 


\section{Conclusions}

Deposited nickel oxide films are polycrystalline structures with the array of whiskers. The whiskers have average diameter and height of 30 and $200 \mathrm{~nm}$, respectively. The rhombohedral crystal lattice is formed in the films deposited on the substrate at the room temperature. Deposition on the heated to $250-300^{\circ} \mathrm{C}$ substrate leads to formation of the films with the cubic crystal lattice. Increase of the deposition rate leads to the array formation of $\mathrm{NiO}_{x}$ crystallites with the much more uniformity of sizes and increase of the average crystallite size. Increase of the substrate temperature during deposition leads to formation of the $\mathrm{NiO}_{x}$ films with the more dense structure.

\section{References}

1. D.S.Dalavia, M.J.Suryavanshi, D.S.Patil et al., Appl.Surf.Sci, 257, 2647 (2011).

2. Ying Mua, Dongling Jia, Yayun Hea et al., Biosens. and Bioelectron., 26, 2948 (2011).

3. Se-W.Parka, Jeong-M.Choia, Eugene Kimb, Seongil Ima, Appl. Surf. Scie., 244, 439 (2005).

4. Lili Wang, Zheng Lou, Rui Wang et al., J. Mater. Chem., 22, 12453 (2012).

5. O.S.Oberemok, V.P.Melnik, V.A.Nikirin et al., in: Proc. of XV International Conference "Physics and Technology of Thin Films and Nanosystems", May 11-16 (2015), p.81.

6. G.Granqvist Claes, Thin Solid Films, 564, 1 (2014).

7. K.Anandan, V.Rajendran, Struct., Nanoscie.. .Nanotechn.: An Intern. J., 2, 24 (2012).

8. V.Biju, M.Abdul Khadar, Spectrochim. Acta, Part A, 59, 121 (2003). 